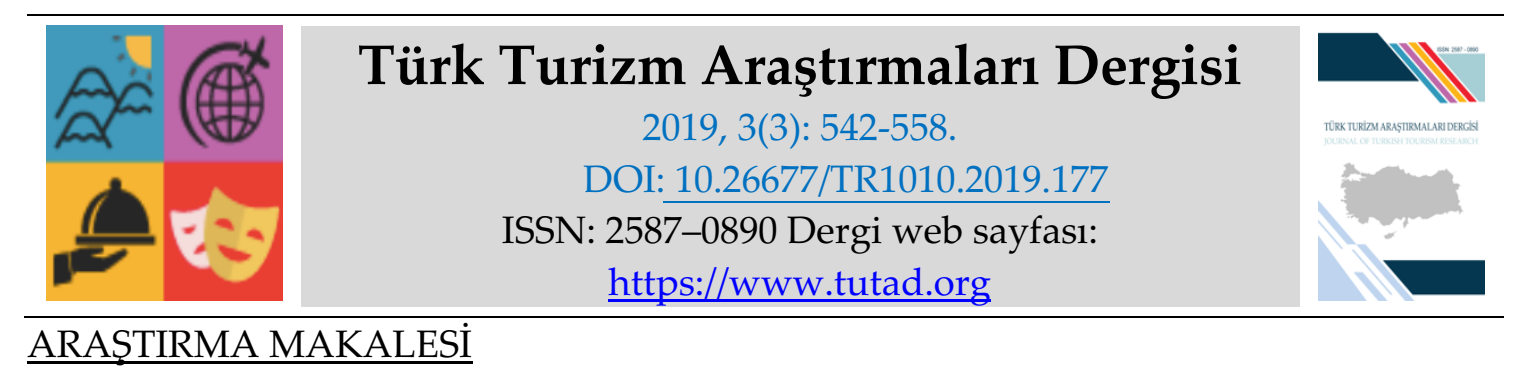

\title{
Şehir Turizminde Faaliyet Gösteren Otellere Yönelik E-Yorumların İncelenmesi: Eskişehir İli Örneği
}

Seda ÇOBAN, Anadolu Üniversitesi, Turizm İşletmeciliği Yüksek Lisans Öğrencisi, Eskişehir, eposta: sedacoban@anadolu.edu.tr ORCID: https://orcid.org/0000-0003-2884-8081

Eda ÇOBAN, Anadolu Üniversitesi, Turizm İşletmeciliği Yüksek Lisans Öğrencisi, Eskişehir, eposta: edacoban@anadolu.edu.tr ORCID: https://orcid.org/0000-0003-1032-4992

Dr. Öğr. Üyesi Duygu YETGİN, Anadolu Üniversitesi Turizm Fakültesi Turizm Rehberliği Bölümü, Eskişehir, e-posta: dyetgin@anadolu.edu.tr

ORCID: https://orcid.org/0000-0002-9909-4523

Öz

Günümüzde artık daha bilgili ve araştırmacı olan turistler, seçimlerinde temkinli olmakta ve sosyal medyayı aktif olarak kullanmaktadır. Bu turistler için konaklama tercihinde en önemli bilgi kaynaklarından biri çevrimiçi tüketici yorumlarıdır. Sadece bireysel olarak seyahat eden turistler değil aynı zamanda paket tur programı hazırlayan seyahat acentaları temsilcileri de otel seçimlerinde bu bilgi kaynaklarından yararlanabilmektedir. Bu çalışmada, şehir turizmine katılan turistlerin şehir otelleri hakkındaki beklentilerinin ortaya çıkarılması amaçlanmıştır. Bu amaç doğrultusunda, 2019 Ocak-Şubat tarihleri arasında, Türkiye'de şehir turizmi ile ön plana çıan Eskişehir' de faaliyet gösteren 10 adet şehir oteline yönelik TripAdvisor web sitesinde çeşitli dillerde yapılan 940 adet olumlu ve olumsuz yorum incelenmiş ve bu yorumların en çok hangi kategoriler altında toplandığı tespit edilmiştir. Veriler içerik analizine tabi tutularak yedi ana tema üzerinden değerlendirilmiştir. Araştırma sonucunda yorumların sırasılyla "insan kaynakları" temasında personelin güler yüzlü olması, "yiyecek ve içecek" temasında kahvaltı/yemeğin lezzetli olması, "kat hizmetleri" temasında ise odaların temiz olması konularında yoğunlaştı̆̆ tespit edilmiştir.

Anahtar Kelimeler: Şehir Turizmi, Çevrimiçi tüketici yorumları, TripAdvisor, İçerik Analizi, Eskişehir.

Makale Gönderme Tarihi: 19.05.2019

Makale Kabul Tarihi: 04.07.2019

\section{Önerilen Atıf:}

Çoban, S., Çoban, E. ve Yetgin, D. (2019). Şehir Turizminde Faaliyet Gösteren Otellere Yönelik EYorumların İncelenmesi: Eskişehir İli Örneği, Türk Turizm Araştırmaları Dergisi, 3(3): 542-558.

(C) 2019 Türk Turizm Araştırmaları Dergisi. 


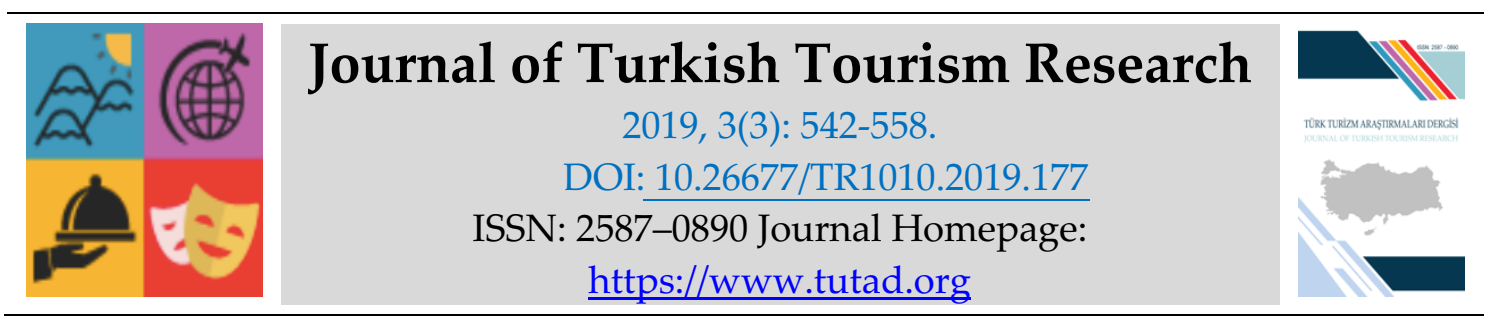

\title{
$\underline{\text { RESEARCH PAPER }}$
}

\section{An Analysis of E-Comments on Hotels that Offer Service in the Field of Urban Tourism: The Case of Eskişehir Province}

Seda ÇOBAN, Anadolu University, Tourism Management Graduate Student, Eskişehir, e-mail: sedacoban@anadolu.edu.tr ORCID: https://orcid.org/0000-0003-2884-8081

Eda ÇOBAN, Anadolu University, Tourism Management Graduate Student, Eskişehir, e-mail: edacoban@anadolu.edu.tr ORCID: https://orcid.org/0000-0003-1032-4992

Assistant Prof. Dr. Duygu YETGİN, Anadolu University, Faculty of Tourism, Eskişehir, e-mail: dyetgin@anadolu.edu.tr ORCID: https://orcid.org/0000-0002-9909-4523

\begin{abstract}
Today, the tourists are more insightful and inquisitive, and they now chose to be more cautious on their preferences and they actively use social media. Online customer comments are one of the most important sources of information that have strong impact on tourists' accommodation preferences. Not only the individual tourists use these online customer comments, but the travel agencies that prepare package tour programs also benefit from these sources of information when selecting hotels. In this study, we aimed to reveal the expectations of tourists involved in urban tourism activities regarding city hotels. For this purpose, 940 positive and negative TripAdvisor comments made between January-February 2019 for 10 city hotels in Eskişehir in various languages were reviewed, and the most common categories of these comments were determined. The data obtained were processed through content analysis and were then evaluated through seven main themes. At the end of this analysis, it was found that the comments mainly focused on personnel's attitude in "human resources" theme, tastiness and quality of breakfast/food in "food \& beverage" theme, and cleanliness of rooms in "housekeeping" theme, respectively.
\end{abstract}

Keywords: Urban Tourism, Online Customer Comments, TripAdvisor, Content Analysis, Eskişehir.

Received: 19.05 .2019

Accepted: 04.07.2019

Suggested Citation:

Çoban, S., Çoban, E. and Yetgin, D. (2019). An Analysis of E-Comments on Hotels that Offer Service in the Field of Urban Tourism: The Case of Eskişehir Province, Journal of Turkish Tourism Research, 3(3): 542-558.

(c) 2019 Türk Turizm Araştırmaları Dergisi. 


\section{Gíriş}

Turizmde, üretim ile tüketimin eş zamanlı olması nedeniyle turistlerin satın alacakları/aldıkları turistik ürün ya da hizmeti daha önceden deneyimleme/görme imkanı yoktur (Hacıoğlu ve Avcıkurt, 2011: 7). Turistik ürünün bu özelliklerinden dolayı potansiyel turistler, satın alma öncesinde mal ya da hizmetten haberdar olma gereksinimi hissetmektedir. Bu durumda seyahatini planlama aşamasında olan potansiyel turistin ilk önceliği, gereksinim duyduğu bilgiler için çeşitli bilgi kaynaklarına başvurmak olmaktadır (Genç ve Batman, 2018: 284). Bu bilgi kaynakları sayesinde turistler dünyanın herhangi bir yerindeki bir ürün veya destinasyon hakkında bilgi edinebilmekte (Akoğlan Kozak ve Bahçe, 2012: 85) ve kendileri de bu ürün veya destinasyon hakkında bilgi paylaşabilmektedir. Özellikle son yıllarda popüler olan ve müşterilerin ürünler ve hizmetler hakkında tarafsız yorum yapmalarına olanak veren çevrimiçi tüketici siteleri (Hennig Thurau vd., 2004: 39), tüketicilerin tatil destinasyonu seçiminde en güvenilir elektronik ağızdan ağıza pazarlama formlarından biridir (Güdü Demirbulat ve Aymankuy, 2016: 72).

Çevrimiçi tüketici siteleri sayesinde turistler işletmelerde yaşadıkları olumlu ve olumsuz deneyimlerini paylaşmakta ve işletme hakkında değerlendirme yapmaktadır. İşletmeden memnun ayrilan müşteriler olumlu deneyimlerini çevresine anlatabilmekte (Ok vd., 2018: 23) ve tekrar aynı işletmeye giderek işletmenin sadık müşterisi olabilmektedir. Hizmet sunan turizm işletmelerinde mevcut müşteriyi elde tutmanın maliyetinin yeni müşteri kazanmanın maliyetinden daha düşük olması (Lin ve Wang, 2005) müşteri memnuniyeti ve sadakatine verilmesi gereken önemi göstermektedir. Müşteri memnuniyeti ve sadakatini sağlamanın yolu ise düzenli olarak müşteri beklentilerini ölçmek ve müşterilerin beklentileri doğrultusunda mal ve hizmetleri geliştirmektir (Çatı ve Koçoğlu, 2008: 2). Bu doğrultuda konaklama işletmelerinin çevrimiçi tüketici yorumlarını düzenli olarak incelemesi ve yorumlara konu olan odaların temizliği, personelin tutum ve davranışları, sunulan yiyecek-içeceğin kalitesine gereken önemi vermesi müşteri memnuniyeti açısından önem taşımaktadır.

Bu çalışmanın amacı, şehir turizmine katılan turistlerin şehir otelleri hakkındaki beklentilerinin ortaya çıarılmasıdır. Bu amaç doğrultusunda, dünyanın en büyük seyahat sitesi olan TripAdvisor web sitesinde, Eskişehir' de bulunan 10 adet dört ve beş yıldızlı şehir oteline yönelik turistlerin olumlu ve olumsuz yorumları incelenmiş ve bu yorumların en çok hangi kategoriler altında toplandığı tespit edilmiştir. Çalışmada Eskişehir ilinin tercih edilmesinin nedeni; şehrin özellikle son yıllarda iç turizmde ve şehir turizminde önemli bir destinasyon olarak ivme kazanmaya başlamasıdır. Çalışmadan elde edilen bulgular, Eskişehir ilinde şehir turizmine yönelik turist yorumlarının incelendiği bir çalışmanın bulunmaması nedeniyle ilgili literatüre ve sektöre katkı sağlaması açısından önem taşımaktadır.

\section{KAVRAMSAL ÇERÇEVE}

\section{Şehir Turizmi}

Şehirler, sahil veya kırsal destinasyonlardan farklı olarak, ziyaretçilere sundukları canlı ve çok yönlü atmosfer ile giderek daha popüler destinasyon haline gelmektedir (Uca Özer, 2010: 4). Bu destinasyonların canlılığını sağlayan en önemli unsur ise o kentte gerçekleştirilen turizm faaliyetleridir. Bu kapsamda şehirlerde gerçekleştirilen turizm faaliyetleri, tarihi ve kültürel çekiciliklerin, tiyatroların, müzelerin, sergilerin, alışveriş merkezlerinin, sanat galerilerinin gösteri ve şov mekânlarının, kafe ve restoranların, temalı eğlence parklarının ve aqua parkların ziyaretlerini içeren, rekreatif aktivitelere önem veren bir eğilimi içermektedir (Kozak vd., 2017: 41). Literatür incelediğinde şehir turizmi ile ilgili farklı tanımların yapıldığı görülmektedir. Şehir 
turizmi, en genel tanımıyla şehirlerde gerçekleştirilen turizm amaçlı etkinlikleri içeren faaliyetlerdir (Jurdana ve Susilovic, 2006: 137). Emekli' nin (2011) tanımına göre ise şehir turizmi, turistlerin diğer toplumların tarihi ve kültürel mirası veya çağdaş yaşam tarzlarını, düşünce biçimlerini öğrenmek için gerçekleştirdikleri tüm ziyaret türleridir.

Günümüzde şehir turizmi kapsamında hafta sonları ya da kısa tatillerde ulaşımı kolay ve ucuz, güvenli bir kente gitmek, bir iki gece konaklamak yükselen bir eğilim olarak dikkat çekmektedir. İnsanlar artık tatil planlarını yaparken yaz mevsimi ve yıllık izinlerini kullanmayı beklemek yerine kısa kaçışlarla kendilerini yenilemek ve deneyim yaşamak istemektedir (Emekli, 2011: 30). Şehir turizmine katılan turistlerin seyahat süreleri kısa olmakta (1-3 gün) ve daha çok oda kahvaltı hizmeti veren konaklama işletmelerini tercih etmektedirler (Uca, 2019: 26). Şehirler farklı kültürel yapıları ile turizm sektörünün önemli çekim merkezleri arasında yer almaktadır. Son yıllarda çok sayıda yerli ve yabancı turist, sadece o şehri yaşayıp kent dokusunu hissetmek (Giritlioğlu ve Avcıkurt, 2010) ve kendi yaşadığı şehirden farklı olan şeyleri keşfetmek için bağımsız olarak ya da paket turlar aracılığıyla o şehirleri ziyaret etmektedir. Günümüzde ülkemizde şehir turizmi ile adından sıkça söz ettiren kentlerden biri de Eskişehir'dir. 2000'li yıllardan itibaren turizmde gelişme gösteren Eskişehir, 2005-2006 yılından itibaren ise şehir turizminde önemli bir destinasyon olarak tanınmaya başlamıştır (Aydın, 2016: 18).

Eskişehir'in şehir turizminde ivme kazanmasının başlıca etkenleri; Eskişehir'in en eski yerleşim yerlerinden biri olan Tarihi Odunpazarı Evleri, yıl boyu yapılan etkinlikler (festivaller, tiyatrolar, gösteriler vb.), Porsuk Çayı, çeşitli rekreasyon faaliyetlerinin gerçekleştirilebileceği Kent Park, Sazova Bilim Sanat ve Kültür Parkı, şehirde yer alan müzelerdir (Yılmaz Büyükerşen Balmumu Heykeller Müzesi, Kurtuluş Müzesi, , Lületaşı Müzesi, Çağdaş Cam Sanatları Müzesi, Eskişehir Eti Arkeoloji Müzesi, Yunus Emre Müzesi vb.). Evren ve Kozak (2012) tarafından Eskişehir'in çekici faktörlerini belirlemeye yönelik yapılan çalışmada, Eskişehir'e yönelik yapılan ziyaretlerin en başında "gezi-eğlence", daha sonra ise "tarihi ve kültürel değerleri" görme amacı olduğu sonucuna ulaşılmıştır. Eskişehir'in şehir turizminde gelişmesinde önemli payı olan bu çekiciliklerin yanı sıra şehrin havayolu, karayolu ve demiryolu ağı ile güçlü bir ulaşım altyapısına sahip olması ve önemli bir kavşak noktasında bulunmasının da etkisi büyüktür (Eskişehir İl Kültür ve Turizm Müdürlüğü, 2019). Çünkü bir destinasyon çekiciliği yüksek olmasına rağmen yeterli ulaşım altyapısına sahip değilse o destinasyonda turizm faaliyetlerinin gerçekleştirilmesinde güçlükler yaşanabilmektedir (Kozak vd., 2017: 72-73). Ayrıca Eskişehir'in 2013 yılında Türk Dünyası Kültür Başkenti olarak seçilmesi de şehrin turizm yönünden gelişmesine neden olan önemli faktörlerdendir.

İç turizmin gelişmesiyle birlikte özellikle son yıllarda şehir turizminde önemli bir destinasyon olma yolunda ilerleyen Eskişehir'in turistik taşıma kapasitesinin dikkate alınması sürdürülebilirlik açısından önem taşımaktadır. Seçilmiş ve Kılıç (2018) Eskişehir'in taşıma kapasitesini değerlendirmeye yönelik yaptıkları çalışmada, Eskişehir'in sosyal taşıma kapasitesinin aşılmadığını, yerel halkın turizmin gelişmesiyle beraber olumlu düşünceler içinde olduğunu belirtmiştir. Ayrıca, çalışma sonucunda, psikolojik taşıma kapasitesinin de aşılmadığı ve ziyaretçilerin turizmin gelişmesi ve kalabalığa ilişkin olumsuz düşüncede olmadıkları ortaya konmuştur.

Eskişehir'de 2018 yılı itibariyle belediye ve işletme belgeli toplam 54 tesis bulunmaktadır. Bu tesislerin toplam yatak sayısı ise 5629'dur (Kültür ve Turizm Bakanlığı Yatırım ve İşletmeler Genel Müdürlügü̈, 2018). 2017 ve 2018 yılında Eskişehir'e gelen yerli ve yabancı turistlerin tesise geliş ve geceleme sayıları, ortalama kalış süreleri ve tesis doluluk oranlarına Tablo 1'de yer verilmiştir. 
Tablo 1: İşletme ve Belediye Belgeli Tesis Konaklama İstatistikleri

\begin{tabular}{|c|c|c|c|c|c|c|c|}
\hline & & \multicolumn{3}{|c|}{2017} & \multicolumn{3}{|c|}{2018} \\
\hline & & $\begin{array}{l}\text { İşletme } \\
\text { Belgeli }\end{array}$ & $\begin{array}{l}\text { Belediye } \\
\text { Belgeli }\end{array}$ & Toplam & $\begin{array}{l}\text { İşletme } \\
\text { Belgeli }\end{array}$ & $\begin{array}{l}\text { Belediye } \\
\text { Belgeli }\end{array}$ & Toplam \\
\hline \multirow{3}{*}{$\begin{array}{l}\text { Tesise } \\
\text { Geliş } \\
\text { Sayısı }\end{array}$} & Yabanc1 & 22.135 & 1.589 & 23.724 & 32.400 & 3.009 & 35,409 \\
\hline & Yerli & 313.383 & 83.830 & 397.213 & 395.059 & 159.191 & 554,25 \\
\hline & Toplam & 335.518 & 85.419 & 420.937 & 427.459 & 162.200 & 589,659 \\
\hline \multirow[t]{3}{*}{ Geceleme } & Yabanc1 & 56.790 & 3.539 & 60.329 & 70.997 & 5.788 & 76,785 \\
\hline & Yerli & 489.606 & 115.311 & 604.917 & 587.955 & 216.366 & 804,321 \\
\hline & Toplam & 546.396 & 118.850 & 665.246 & 658.952 & 222.154 & 881,106 \\
\hline \multirow{3}{*}{$\begin{array}{l}\text { Ortalama } \\
\text { Kalış } \\
\text { Süresi } \\
\text { (Gün) }\end{array}$} & Yabanc1 & 2,57 & 2,23 & 2,4 & 2,19 & 1,92 & 2,06 \\
\hline & Yerli & 1,56 & 1,38 & 1,47 & 1,49 & 1,36 & 1,43 \\
\hline & Toplam & 1,63 & 1,39 & 1,51 & 1,54 & 1,37 & 1,46 \\
\hline \multirow{3}{*}{$\begin{array}{l}\text { Doluluk } \\
\text { Oranları } \\
(\%)\end{array}$} & Yabanc1 & 3,77 & 0,88 & 2,33 & 4,83 & 1,05 & 2,94 \\
\hline & Yerli & 32,54 & 28,61 & 30,58 & 40,01 & 39,37 & 39,69 \\
\hline & Toplam & 36,31 & 29,49 & 32,9 & 44,84 & 40,42 & 42,63 \\
\hline
\end{tabular}

Kaynak: Kültür ve Turizm Bakanlığı Yatırım ve İşletmeler Genel Müdürlüğü, 2019.

Tablo 1 incelendiğinde, 2017 yılında turistlerin tesise geliş sayıları 420.937 iken 2018 yılında bu sayının 589.659 olduğu görülmektedir. 2017 yılında geceleme sayısı 665.246 iken, 2018 yılında bu sayı 881,106'ya yükselmiştir. 2017 yılında ortalama kalış süresi 1,51 (1,5 gün) iken, 2018 yılında 1,46 (yaklaşık 1,5 gün) ile bu sürenin azaldığı görülmektedir. Konaklama işletmelerinin doluluk oranlarına bakıldığında, 2017 yılında tesislerin doluluk oranı \%32,9 iken, 2018 yılında bu oranın $\% 42,63$ ' e yükseldiği görülmektedir.

\section{TripAdvisor}

Teknolojik gelişmelerle birlikte günümüz tüketicileri internet üzerinden ürün/hizmet hakkındaki olumlu ve olumsuz deneyimlerini ifade edebilme olanağına sahiptir (Lee ve Hu, 2005). Bu olanağ tüketicilere sağlayan e-WOM (Elektronik ağızdan ağıza iletişim) "Mevcut veya eski müşterilerin internet üzerinden çok sayıda kişiye ve kuruma sunulan bir ürün veya hizmet hakkında yaptığ 1 olumlu veya olumsuz yorum "olarak tanımlanmaktadır (Hennig Thurau vd., 2004: 39). Elektronik yorum olarak nitelendirilen bu bilgi paylaşım aracının en yaygın olduğu alanlardan biri de turizm sektörüdür (Bilim vd., 2013: 388). Günümüzde daha bilgili, araştırmacı, seçimlerinde temkinli olan ve sosyal medyayı aktif olarak kullanan turistler, seyahatlerini gerçekleştirmeden önce diğer müşterilerin deneyimlerini öğrenmek ve işletme hakkında bilgi sahibi olabilmek için çeşitli web sitelerini ziyaret etmektedir. Bu nedenle müşteri ilişkileri 
temeline dayanan ve öncelikli amacı müşterilerine kaliteli hizmet sağlamak ve böylece tatmin olmuş tüketiciler ortaya koymak olan turizm sektöründe (Arpacı ve Vatansever Toylan, 2015: 51) çevrimiçi tüketici yorumları seyahat tercihlerini etkileyebilmektedir.

Günümüzde turizm faaliyetlerine yönelik en çok tercih edilen çevrimiçi web sitelerinden biri TripAdvisor'dır (Jeong ve Mindy Jeon, 2008; O'Connor, 2010). 2000 yılında kurulan TripAdvisor web sitesi, yaklaşık 7,7 milyon işletmenin yer aldığı, 661 milyonu aşkın yorum ve görüşün bulunduğu, çoğunluğun deneyimlerine dayalı görüşleri gezginlere sunan dünyanın en büyük seyahat sitesidir (TripAdvisor, 2019). Her ay milyonlarca (455 milyon) tüketici, seyahatleri için TripAdvisor web sitesini kullanmaktadır (Law, 2006: 75). Bu tüketicilerin yüzde 97'si bir sonraki seyahatini planlamak için siteyi tekrar ziyaret etmektedir (Reiter, 2007: 12). Ayrıca TripAdvisor, kullanıcılar tarafından yapılan tüm yorumların, içerik kurallarına uygun olup olmama durumunu öncelikle incelemektedir. Daha sonra kurallara uygun olan bu yorumlar onaylanarak süresiz olarak yayınlanmakta ve görüntülenmektedir (O'Connor, 2010: 761).

Literatür incelendiğinde konaklama işletmeleri ile ilgili çevrimiçi tüketici yorumlarını incelemeye yönelik birçok çalı̧̧maya rastlanmıştır. Nicoli ve Papadopoulou (2017), TripAdvisor'ın otel endüstrisindeki önemini belirlemeye yönelik yaptıkları çalışmada, otel yönetiminin tüketici yorumlarını sürekli izlediği ve hızlı tepkiler verdiği sonucuna ulaşmıştır. Bu çalışmaya benzer nitelikteki başka bir araştırmada ise O'Connor (2010) otel yönetiminin tüketici yorumlarını ne derece ciddiye aldıklarını incelemiştir. Araştırma sonucunda az sayıda otelin TripAdvisor web sitesinde yer alan yorumları dikkate aldıkları ortaya konmuştur. Fong, Lei ve Law'ın (2017) çevrimiçi tüketici yorumlarını inceledikleri çalışmada, erkeklerin otellere verdikleri puanların düşük olduğu, kadınların verdikleri puanların ise daha yüksek olduğu sonucuna ulaşılmıştır. Chang, Ku ve Chen (2017) tarafından sanal tüketici yorumlarıyla ilgili yapılan başka bir çalışmada ise, Hilton otellerine yönelik iş seyahati yapanların düşük puan verdikleri, çiftlerin ise daha yüksek puan verdikleri sonucuna ulaşılmıştır. Bu çalışma sonucuna benzer olarak Banerjee ve Chua (2016) çevrimiçi ziyaretçi profilini belirlemek amacıyla yaptıkları çalışmada, iş seyahati yapanların düşük puan verdiği, bunun yanı sıra ziyaretçi profillerinin bölgedeki bağımsız ve zincir oteller arasındaki puanlamalarda büyük fark olduğu sonucu ortaya çımıştır. Limberger vd., (2014) otel müşterilerinin genel memnuniyetlerini belirlemeye yönelik tüketici yorumlarını inceledikleri çalışma sonucunda, genel memnuniyetin oda, servis ve maliyet avantajları kriterleriyle güçlü bir ilişkisi olduğunu ortaya koymuştur.

Çevrimiçi tüketici yorumlarını değerlendirmeye yönelik yapılan çalışmalar incelendiğinde, bu çalışmaların uluslararası literatürde daha önceden yer aldığını, ulusal literatüre ise daha yakın tarihte girdiğini ve hâlâ önemini koruduğunu söylemek mümkündür. Bu bağlamda ulusal literatürde konuyla ilgili yapılan çalışmalara bakıldığında; Doğancili vd., (2018) tarafından yapılan çalışmada, Göller Bölgesi'nde yer alan otellere yönelik çevrimiçi yorumlar incelendiğinde, en çok ele alınan olumlu yorumların sırasıyla personel, temizlik ve yemeğe ilişkin unsurlar olduğu sonucuna ulaşılmıştır. Bilim vd., (2013) tarafından tüketicilerin tatil otellerine yönelik çevrimiçi yorumların incelenmesi ve pazarlama bilgi aracı olarak kullanılmasına etkilerini belirlemek amaciyla yapılan çalışmada, en fazla olumlu yorumun hizmet alanları, yeme-içme özellikleri, genel hizmetler ve tüketici çıtıları ile hizmet personeline yönelik yapıldığı görülmektedir. Çuhadar vd., (2018) tarafından tüketicilerin çevrimiçi değerlendirmeleri ile konaklama işletmelerinin özellikleri arasında ilişkiyi belirlemeye yönelik yapılan çalışmada Isparta ilinde tüketicilerin çevrimiçi otel değerlendirmeleri ile konaklama işletmelerinin çeşitli özellikleri arasında istatistiksel açıdan anlamlı farklılık olduğu sonucuna ulaşılmıştır. Ekici vd., (2017) tarafından ise Antalya'da tema park otel konseptine yönelik tüketiciler tarafından yapılan çevrimiçi yorumların incelendiği çalışmada, konseptin misafirler tarafından beğenildiği, gelecekte tekrar satın alma ve tavsiye etme niyetinin olumlu olduğu sonucuna ulaşılmıştır. 
Gündüz (2015), Pamukkale yöresindeki Sağlık Bakanlığı tarafından belgeli otel müşterilerinin memnuniyetinin belirlenmesine yönelik yaptığı çalışmada, olumlu yorum sayısının olumsuz yorum sayısına göre fazla olduğu ve otellerde konaklayan müşterilerin işletmelerden memnun oldukları sonucuna ulaşmıştır. Genç (2014) tarafından Eskişehir'deki konaklama işletmelerine ait çevrimiçi tüketici yorumlarının incelenmesine yönelik yapılan çalışma sonucunda, Eskişehir'e gelen turistlerin en çok üç yıldızlı otellerde kalmayı tercih ettikleri, daha çok iş amaçlı nedenlerle konakladıkları ve sunulan hizmetin kalitesiyle ilgili yorum yaptıkları ortaya konmuştur.

\section{YÖNTEM}

Bu çalışmada, şehir turizmine katılan turistlerin şehir otelleri hakkındaki beklentilerinin ortaya çıkarılması amaçlanmıştır. Bu amaç doğrultusunda, araştırma verileri nitel araştırma yöntemi benimsenerek Eskişehir'de faaliyet gösteren 4 ve 5 yıldızlı şehir otellerinde konaklayan turistlerin, www.tripadvisor.com web sitesinde yer alan olumlu ve olumsuz yorumları incelenerek elde edilmiştir. Bu doğrultuda www.tripadvisor.com web sitesinde Eskişehir'de faaliyet gösteren yedi tane 4 yıldızlı (The Merlot, Modernity, Capella, Hilton Garden Inn, Saffron, Dedepark, Divan Express) ve üç tane 5 yıldızlı (Tasigo, Park Dedeman, Anemon) toplam 10 adet şehir oteline yönelik 01.01.2017-28.02.2019 tarihleri arasında yapılan çeşitli dillerdeki (Türkçe, İngilizce, İtalyanca, Rusça, Almanca, Fransızca, Lehçe, Yunanca, Hollandaca, Arapça, İspanyolca, Endonezce, İbranice, Japonca, Danca, Çekçe, Macarca) 940 adet yorum Ocak-Şubat 2019 tarihleri arasında incelenmiştir. Toplamda 940 adet yorum incelenmiş olup bir yorumda birden fazla konuya değinilmiş olması göz önünde bulundurulduğunda kod sayısının 2611'e yükseldiği görülmektedir. Araştırma kapsamına alınan bu tarihlerin seçilmesinin nedenlerinden biri Genç'in (2014) 01.02.2010-01.12.2013 tarihleri arasındaki müşteri yorumlarını incelediği çalışmayla karşılaştırma yapabilmektir. Bir diğer neden ise Eskişehir'in iç turizmde ve şehir turizminde son yıllarda gösterdiği gelişmeye rağmen bu tarihten itibaren konuyla ilgili yapılan başka bir çalışmaya rastlanmamasıdır. Bu bağlamda bu çalışma ilgili literatüre ve sektöre katkı sağlaması bakımından önem taşımaktadır.

Çalışmada elde edilen veriler içerik analizi yöntemiyle analiz edilmiştir. İçerik analizi birbirine benzeyen verileri belirli kavramlar ve temalar çerçevesinde bir araya getirmek ve bunları okuyucunun anlayabileceği biçimde düzenlemektir (Yıldırım ve Şimşek, 2006: 227). Yorumların içerik analizi aşamasında iki araştırmacı, birbirinden bağımsız olarak verileri analiz etmiştir. Bu aşamada araştırmacılar elde ettikleri verileri inceleyerek anlamlı bölümlere ayırmış ve her bölümün kavramsal olarak ne anlam ifade ettiğini bulmuştur (Yıldırım ve Şimşek, 2006: 228). Bu doğrultuda ifadelerin tekrar etme sıklığına göre kodlar belirlenmiştir. Çalışmanın güvenirliğini artırmak için kodlayıcılar arasında görüş birliği sağlanmıştır (Creswell, 2013; Silverman, 2005). Bu kapsamda her iki araştırmacının yaptığı analizler tekrar tekrar incelenip iki araştırmacının da hemfikir olduğu temalar ve alt temalar belirlenmiştir. Daha sonra oluşturulan tema ve alt temaların geçerliliğinin sağlanabilmesi için turizm sektöründe deneyimi olan ve alanında uzman üç akademisyenin görüşüne başvurulmuştur. Uzman görüşleri de dikkate alınarak araştırma verilerinin analizi sonucunda yedi ana tema elde edilmiştir. Bunlar; "İnsan Kaynakları", "Yiyecek ve İçecek", "Kat Hizmetleri", "Odalar", "Konum", "Otelin Özellikleri" ve "Otelin İmkanları" olarak belirlenmiştir. Bu analizler sonucunda elde edilen bulgular tablo haline getirilmiştir. 


\section{BULGULAR}

Çalışmadan elde edilen bulgular insan kaynakları, yiyecek ve içecek, kat hizmetleri, odalar, konum, otelin özellikleri ve otelin imkânları olmak üzere yedi ana tema altında toplanmıştır. Çalışma sonucunda elde edilen bulgulara Tablo 2' de yer verilmiştir.

Tablo 2: Konaklama İşletmelerine Yönelik Yorumların İçerik Analizi

\begin{tabular}{|c|c|c|c|c|}
\hline Ana Temalar & Görüssler & Alt Temalar & $\mathbf{n}$ & $\%$ \\
\hline \multirow{9}{*}{ İnsan Kaynakları } & \multirow{8}{*}{ Olumlu } & Güler yüzlü olma & 268 & 10,26 \\
\hline & & İlgili olma & 176 & 6,74 \\
\hline & & Yardımsever olma & 103 & 3,94 \\
\hline & & Kibar olma & 80 & 3,06 \\
\hline & & Sicakkanlı olma & 27 & 1,03 \\
\hline & & Eğitimli olma & 11 & 0,42 \\
\hline & & Saygilı olma & 10 & 0,38 \\
\hline & & Profesyonel olma & 10 & 0,38 \\
\hline & Olumsuz & İlgisiz olma & 7 & 0,27 \\
\hline \multirow{5}{*}{ Yiyecek ve İçecek } & \multirow{4}{*}{ Olumlu } & Kahvaltı çeşidinin bol olması & 144 & 5.52 \\
\hline & & $\begin{array}{l}\text { Kahvaltı/yemeğin lezzetli } \\
\text { olması }\end{array}$ & 201 & 7,7 \\
\hline & & Kahvaltının kaliteli olması & 102 & 3,91 \\
\hline & & Yiyeceklerin taze olması & 5 & 0,19 \\
\hline & Olumsuz & $\begin{array}{l}\text { Kahvaltı çeşidinin yetersiz } \\
\text { olması }\end{array}$ & 32 & 1,23 \\
\hline \multirow{4}{*}{ Kat hizmetleri } & \multirow{3}{*}{ Olumlu } & Odaların temiz olması & 274 & 10,49 \\
\hline & & Genel alanların temiz olması & 89 & 3,41 \\
\hline & & Banyonun temiz olması & 20 & 0,77 \\
\hline & Olumsuz & Odaların kirli olması & 50 & 1,91 \\
\hline \multirow{6}{*}{$\begin{array}{l}\text { Odaların fiziksel } \\
\text { yapısı }\end{array}$} & \multirow{3}{*}{ Olumlu } & Konforlu olması & 215 & 8,23 \\
\hline & & Geniş olması & 122 & 4,67 \\
\hline & & Ferah olması & 23 & 0,88 \\
\hline & \multirow{3}{*}{ Olumsuz } & Eski eşya & 25 & 0,96 \\
\hline & & Kötü ses yalıtımı & 16 & 0,61 \\
\hline & & Küçük olması & 14 & 0,54 \\
\hline \multirow[b]{2}{*}{ Otelin Konumu } & \multirow[b]{2}{*}{ Olumlu } & Şehir merkezine yakınlık & 201 & 7,7 \\
\hline & & Gezilecek yerlere yakınlık & 48 & 1,84 \\
\hline
\end{tabular}




\begin{tabular}{|c|c|c|c|c|}
\hline & & $\begin{array}{lll}\text { Şehir merkezine } & \text { kolay } \\
\text { ulaşım } & & \end{array}$ & 37 & 1,42 \\
\hline & Olumsuz & Şehir merkezine uzaklık & 18 & 0,69 \\
\hline \multirow[t]{3}{*}{ Otelin özellikleri } & \multirow[t]{2}{*}{ Olumlu } & Mimarinin güzel olması & 88 & 3,37 \\
\hline & & Manzaranın güzel olması & 63 & 2,41 \\
\hline & Olumsuz & Çevrenin gürültülü olması & 12 & 0,46 \\
\hline \multirow[t]{7}{*}{ Otelin imkanları } & \multirow[t]{4}{*}{ Olumlu } & Otopark imkanı & 62 & 2,37 \\
\hline & & Hizlı internet & 14 & 0,54 \\
\hline & & Çalışma masasının olması & 5 & 0,19 \\
\hline & & Ütü imkânı & 4 & 0,15 \\
\hline & \multirow[t]{3}{*}{ Olumsuz } & Yetersiz otopark alanı & 20 & 0,77 \\
\hline & & Vale hizmetinin olmaması & 10 & 0,38 \\
\hline & & $\begin{array}{l}\text { Spor salonu malzemelerinin } \\
\text { yetersizliği }\end{array}$ & 5 & 0,19 \\
\hline \multicolumn{3}{|l|}{ TOPLAM } & 2611 & 100 \\
\hline
\end{tabular}

Tablo 2'de görüldüğü üzere verilerin analizi sonucunda (1) insan kaynakları, (2) yiyecek ve içecek, (3) kat hizmetleri, (4) odaların fiziksel yapısı, (5) otelin konumu, (6) otelin özellikleri, (7) otelin imkânları olmak üzere yedi ana tema belirlenmiştir. "İnsan kaynakları"nın oluşturduğu ana temada; güler yüzlü olma, ilgili olma, yardımsever olma, kibar olma, sıcakkanlı olma, eğitimli olma, saygılı olma, profesyonel olma olumlu alt temaları ile ilgisiz olma olumsuz alt teması yer almaktadır. "Yiyecek ve içecek" ana teması altında, kahvaltı çeşidinin bol olması, kahvaltı/yemeğin lezzetli olması, kahvaltının kaliteli olması ve yiyeceklerin taze olması olumlu alt temaları ile kahvaltı çeşidinin yetersiz olması olumsuz alt teması yer almaktadır. "Kat hizmetleri" ana temasında odaların temiz olması, genel alanların temiz olması ve banyonun temiz olması olumlu alt temaları ile odaların kirli olması olumsuz alt teması yer almaktadır. "Odaların fiziksel yapısı" ana teması, konforlu olması, geniş olması ve ferah olması olumlu alt temaları ile eski eşya, kötü ses yalıtımı ve küçük olması olumsuz alt temalarından oluşmaktadır. "Otelin konumu" ana temasında, şehir merkezine yakınlık, gezilecek yerlere yakınlık ve şehir merkezine kolay ulaşım, olumlu alt temaları ile şehir merkezine uzaklık olumsuz alt teması yer almaktadır. "Otelin özellikleri" ana teması altında, mimarinin güzel olması ve manzaranın güzel olması olumlu alt temaları ile çevrenin gürültülü olması olumsuz alt teması yer almaktadır. "Otelin imkânları" ana temasında, otopark imkânı, hızlı internet, çalışma masasının olması ve ütü imkânı olumlu alt temaları ile yetersiz otopark alanı, vale hizmetinin olmaması ve spor salonu malzemelerinin yetersizliği olumsuz alt temaları yer almaktadır.

\section{Insan Kaynakları}

Turizm endüstrisi, emek yoğun bir özelliğe sahip olması nedeniyle yoğun insan ilişkilerine dayanmaktadır. Personelin kendi içindeki ilişkilerinin yanı sıra müşterinin personel ile olan 
ilişkileri oldukça önemlidir. Buna bağlı olarak personelin güler yüzlü olması, işini isteyerek ve severek yapması, alanıyla ilgili yeterli bilgi birikimine sahip olması ve nazik olması müşteri ilişkilerini doğrudan etkilemektedir (Akoğlan Kozak, 2009: 3). Tablo 2 incelendiğinde temalar içinde en fazla yorumun insan kaynakları (692) ana teması altında toplandığı görülmektedir. Bu ana tema altında; sırasıyla güler yüzlü $(\% 10,26)$, ilgili $(\% 6,74)$, yardımsever $(\% 3,94)$ kibar $(\% 3,06)$, sıcakkanlı $(\% 1,03)$, eğitimli $(\% 0,42)$, saygılı $(\% 0,38)$ ve profesyonel olma $(\% 0,38)$ şeklindeki olumlu alt temaların yanı sıra ilgisiz olma $(\% 0,27)$ olumsuz alt teması da yer almaktadır. Aşağıda müşterilerin insan kaynakları ana temasına yönelik yaptıkları olumlu ve olumsuz yorumlara yer verilmektedir:

- "Personel çok nazik ve tüm isteklerinize cevap verecek kadar tecrübeliydi."

- $\quad$ "Öncelikle otelin güler yüzlü ve misafirperver personeli hemen dikkatinizi çekiyor"

- $\quad$ "...resepsiyondan mutfağa tüm personel güler yüzlü ve çözüm odaklıydı"

- "Bu kadar ilgisiz ve alakasız çalışanları bulmak da zor olsa gerek."

\section{Yiyecek ve İçecek}

İnsan ihtiyaçları içinde yaşamın devamı için zorunlu bir gereksinim olan yeme içme hizmetleri konaklama işletmelerinde önemli bir yer tutmaktadır (Denizer, 2011: 4). Müşteriler yemeğin lezzetinden görsel sunumuna, çeşidinden hijyenine kadar birçok konuya özen göstermektedir. Bu nedenle otelin sunduğu hizmetler arasında konuklar tarafından en çok izlenen ve eleştirilen yiyecek ve içecek hizmetleri otelin genel değerlendirilmesinde önemli rol oynamaktadır (Sarışık, 2016: 239). Ayrıca şehir otellerinde toplantı ve banket salonları otel yönetimine gelir sağlayan kalemlerin başında gelmektedir. Çalışmada yiyecek ve içecek (484) ana teması, insan kaynakları ana temasından sonra en fazla yorum alan kategoriler arasında yer almaktadır. Yiyecek ve içecek ana teması altında sırasıyla kahvaltı/yemeğin lezzetli olması $(\% 7,7)$, kahvaltı çeşidinin bol olması $(\% 5,52)$, kahvaltının kaliteli olması $(\% 3,91)$, yiyeceklerin taze olması $(\% 0,19)$ olumlu alt temalarının yanı sıra, kahvaltı çeşidinin yetersiz olması $(\% 1,23)$ olumsuz alt teması da yer almaktadır. Yiyecek ve içeceklerle ilgili yapılan yorumlara bakıldığında kahvaltı ve yemek çeşidinin lezzetli olması olumlu yorumlar arasında yer alırken, yetersiz kahvaltı çeşidi ise olumsuz yorumların yapıldığı alt tema olarak belirlenmiştir. Aşağıda müşterilerin yiyecek ve içecek ana temasına yönelik yaptıkları olumlu ve olumsuz yorumlara yer verilmektedir:

- "Yemeklerin çeşitliliği ve ürünlerin tazeliği dikkat çekici seviyede iyiydi..."

- "Kahvaltı birçok otelde göremeyeceğiniz çeşitliliğge sahip"

- "Kahvaltı çeşit ve lezzet açısından çok yeterli..."

- " "...kahvaltı menüsü daha çeşitli olabilirdi"

\section{Kat Hizmetleri}

Temizlik, bakım ve estetik görünümü sağlayan bir hizmet alanı olan kat hizmetleri otel işletmelerinde önemli bir yere sahiptir (Akoğlan Kozak, 2005: 2). Aynı oda içerisindeki banyo, balkon, yatak ve diğer alanların birçok insan tarafından kullanılması nedeniyle müşteriler odaların temizliği ve hijyeni konusunda hassas olabilmektedir (Kuru, 2005: 147). Bu nedenle odaların ve genel alanların temizliği üzerinde durulması gereken önemli bir konudur. Çalışmada kat hizmetleri (433) ana teması altında sırasıyla, odanın temiz olması (\%10,49), genel alanların temiz olması $(\% 3,41)$ ve banyonun temiz olması $(\% 0,77)$ olumlu alt temaların yanı sira, odanın kirli olması $(\% 1,91)$ olumsuz alt teması da yer almaktadır. Aşağıda müşterilerin kat hizmetleri ana temasına yönelik yaptıkları olumlu ve olumsuz yorumlara yer verilmektedir: 
- " "Kahvaltıdan döndüğümde her defasında odam tertemizdi"

- " "... Odalar ve banyo oldukça temiz...."

- "Otel çok temiz ve bakımliydr"

- " "Oda çok kirliydi, çarşaflarda saçlar vardı, halılar aşırı derecede kirliydi"

\section{Odalarn Fiziksel Yapısı}

Tatil veya iş amacıyla seyahat eden müşteriler konaklayacakları odalarda evlerindeki konforu hissetmek isterler. Bu nedenle müşteriler otel rezervasyonu yaptırırken odaların fiziksel özelliklerini de göz önünde bulundurmaktadır. Çalışmada odalar (415) ana temasının altında sırasıyla konforlu olması $(\% 8,23)$, geniş olması $(\% 4,67)$ ve ferah olması $(\% 0,88)$ olumlu alt temaların yanı sıra, eski eşya $(\% 0,96)$, kötü ses yalıtımı $(\% 0,61)$ ve küçük olması $(\% 0,54)$ olumsuz alt temaları da yer almaktadır. Aşağıda müşterilerin odaların fiziksel yapısı ana temasına yönelik yaptıkları olumlu ve olumsuz yorumlara yer verilmektedir:

- "Eşim ve oğlum ile bir gece konakladık. Çok memnun kaldık. Odalar geniş ve ferahtı..."

- "Kaldığımız oda oldukça geniş ve ferahtı. Odadan çok memnun kaldık"

- "Odalar güzel ama alt, üst, sağ, sol odalarn hepsinden gürültü geliyordu ve koridorun ses geçirgenliği biraz yüksekti. Tüm gece uyuyamadık..."

- "Otel odasındaki tüm eşyalar eski püskü, zevksiz ve bakımsız. Çekmecenin kulpu kırık, mobilyalar eski ve yataklar çökmüştü."

\section{Otelin Копити}

Müşteriler açısından konaklama yapacakları otelin personeli, temizliği, yiyecek içeceği gibi faktörlerin yanı sıra otelin bulunduğu konum da önem taşımaktadır. Çünkü müşteriler vakitlerini yalnızca otelde değil, otelin etrafında bulunan çeşitli kafe, alışveriş merkezi, gezilecek yerlerde de geçirebilmektedir. Bu nedenle otelin şehir merkezine ve turistik mekânlara yakınlığı, ulaşımın sağlanabileceği bir bölgede olup olmaması otel tercihinde önemli role sahiptir (Doğan ve Gencan, 2013: 78). Çalışmada otelin konumu (304) ana temasının altında, şehir merkezine yakınlık $(\% 7,7)$, gezilecek yerlere yakınlık $(\% 1,84)$, şehir merkezine kolay ulaşım $(\% 1,42)$ olumlu alt temaların yanı sıra, şehir merkezine uzaklık $(\% 0,69)$ olumsuz alt teması da yer almaktadır. Aşağıda müşterilerin otelin konumu ana temasına yönelik yaptıkları olumlu ve olumsuz yorumlara yer verilmektedir:

- "Otel şehir merkezine çok yakın yeni bir bölgede, alışveriş merkezi E*****'a yürüyüş̧ mesafesinde, Porsuk çayına da yakın. Eskişehir'e gidenler kesinlikle burada kalmalı..."

- "Otelin bulunduğu konum çok güzel, pek çok alışveriş merkezi ve restorana çok yakın..."

- "Otelin ulaşımı kolay ve şehir merkezine çok yakın..."

- "Otel merkeze uzak yürüyerek ulaşamazsinız. Fakat taksi ile merkeze ulaşım sağlanabilir"

\section{Otelin Özellikleri}

Müşterilerin konaklama tercihlerinde etkili olan önemli unsurlar arasında otelin manzarası, dış görünüşü ve otel çevresinin sessiz veya gürültülü olması yer almaktadır. Çalışmada otelin özellikleri (163) ana temasının altında; mimarinin güzel olması (\%3,37), manzaranın güzel olması $(\% 2,41)$ olumlu alt temaların yanı sıra, çevrenin gürültülü olması $(\% 0,46)$ olumsuz alt teması da yer almaktadır. Aşağıda müşterilerin otelin özellikleri ana temasına yönelik yaptıkları olumlu ve olumsuz yorumlara yer verilmektedir: 
- $\quad$ "İki çocuklu bir aile olduğumuzdan orman manzaralı bir suitte konakladık. Önceki gün kar yă̆mış olması sebebiyle kartpostal manzarası gibi bir manzaramız vardı"

- "Otel tepedeki konumu sebebiyle tüm Eskişehir manzarasına hakim. Kesinlikle tavsiye ediyorum"

- "Otelin mimarisi insan rahatlatıyor..."

- "Camı açmayın, ana yola çok yakın olduğu için gürültü̈lü oluyor"

\section{Otelin Imkanları}

Çeşitli amaçlarla seyahat eden müşteriler otelde konakladıkları süre içinde otelin sunduğu tüm imkanlarından yararlanmayı arzulamaktadır. Bu bağlamda imkanların erişilebilirliği, yeterli veya yetersiz olması yorumlara da yansımaktadır. Çalışmada otelin imkanları (120) ana temasının altında otopark imkanı $(\% 2,37)$, hızlı internet (\%0,54), çalışma masasının olması $(\% 0,19)$ ve ütü imkanı $(\% 0,15)$ olumlu alt temaların yanı sıra, vale hizmetinin olmaması $(\% 0,38)$, yetersiz otopark alanı $(\% 0,77)$ ve spor salonu malzemelerinin yetersizliği $(\% 0,19)$ olumsuz alt temaları da yer almaktadır. Aşağıda müşterilerin otel imkanları ana temasına yönelik yaptıkları yorumlara yer verilmektedir:

- " "...otelin hemen yanında otoparkının olması benim için önemli bir unsur"

- $\quad$ "Otelin en güzel yanlarından biri kablosuz internet hızı ve odalarda ütü bulunmasi"

- $\quad$ "Vale hizmeti olmadığından otele geldiğimizde bavullarımıla kapının önünde beklemek zorunda kaldık. Check-in den sonra aracımızı kendimiz otoparka aldık"

- "Otopark alant yetersiz ve Ö******'in otoparkına yönlendiriliyorsunuz"

\section{TARTIŞMA}

Müşteri istek ve ihtiyaçlarına cevap verebilmek değişen dünyaya uyum sağlamada bir zorunluluk haline gelmiştir. Bu noktada yeni teknolojik gelişmelerden yararlanma, işletmelerin karşı karşıya kaldığı önemli konulardan biridir. Özellikle son yıllarda internet kullanımının yaygınlaşmasıyla birlikte müşteriler çevrimiçi tüketici sitelerini daha fazla ziyaret etmeye başlamıştır. Bu kapsamda çevrimiçi tüketici yorumlarının işletmeler tarafından dikkate alınması ve yapılan yorumlara kısa süre içinde geri dönüş yapılması müşteri memnuniyeti açısından işletmeye olumlu katkılar sağlayacaktır. Bu noktadan hareketle yapılan bu çalışmada, Eskişehir'de faaliyet gösteren şehir otellerine yönelik TripAdvisor web sitesinde yer alan olumlu ve olumsuz tüketici yorumlarının incelenmesi ve bu yorumların en çok hangi kategoriler altında toplandığının tespit edilerek şehir turizmine katılan turistlerin şehir otelleri hakkındaki beklentilerinin ortaya çıkarılması amaçlanmıştır. Yapılan bu çalışma, Eskişehir ilinde şehir turizmine yönelik turist yorumlarının incelendiği bir çalışmanın bulunmaması nedeniyle şehir turizmi literatürüne ve sektöre katkı sağlaması açısından önemlidir.

Çalışmada çevrimiçi tüketici yorumları yedi ana tema ve otuz sekiz alt tema altında analiz edilmiştir. Çevrimiçi yorumlar analiz edildiğinde en fazla yorum yapılan ana tema \%26,48'lik bir oranla "insan kaynakları" dır. Bu kategori altındaki yorumlar incelendiğinde, öne çıkan ilk üç olumlu alt tema sırasıyla; personelin güler yüzlü, ilgili ve yardımsever olması iken, personelin ilgisiz olması ise olumsuz alt temada yer alarak dikkat çekmektedir. İnsan kaynaklarından sonra en fazla yorum yapılan ikinci ana tema ise \%18,55 ile "yiyecek ve içecek" ana temasıdır. Bu ana tema altında yer alan ilk üç olumlu alt tema sırasıyla; kahvaltı çeşidinin bol olması, kahvaltı/yemeğin lezzetli olması, kahvaltının kaliteli olmasıdır. Bu kategori altındaki olumsuz alt tema ise, kahvaltı çeşidinin yetersiz olmasıdır. Müşteriler tarafından üçüncü olarak en çok yorum alan ana tema ise \%16,58 ile "kat hizmetleri" dir. Kat hizmetleri ana teması altında yer alan ilk üç 
olumlu alt tema sırasıyla; odaların temiz olması, genel alanların temiz olması ve banyonun temiz olması iken, odaların kirli olması ise olumsuz alt temayı oluşturmaktadır.

Literatür incelendiğinde bu sonuçların konuyla ilgili yapılan diğer çalışma sonuçlarıyla benzerlik gösterdiği anlaşılmaktadır. Bilim vd., (2013), Antalya ilinde yer alan tatil otellerine yönelik tüketici yorumlarını değerlendirdiği çalışmada, en çok yorumun personele yönelik yapıldığ sonucuna ulaşmıştır. Doğancili vd., (2018) tarafından yapılan çalışma da bu sonuçları destekler niteliktedir. Göller Bölgesi'nde yer alan otel işletmelerine yönelik yapılan çevrimiçi tüketici yorumlarının incelendiği bu çalışmada, en çok yorum alan ana temanın personel olduğu tespit edilmiştir. Arpacı ve Vatansever Toylan (2015), turizm sektöründe faaliyet gösteren işletmelere yönelik yapılan şikayetleri tespit etmek amacıyla yaptıkları çalışmada, konaklama işletmelerine yönelik en fazla şikayetin personele yönelik olduğu sonucuna ulaşmıştır. Gündüz (2015), Pamukkale yöresindeki Sağlık Bakanlığı tarafından belgeli otel müşterilerinin memnuniyetinin belirlenmesine yönelik yaptığı çalışma sonucunda yiyecek içeceğin en çok yorum alan ilk üç tema arasında yer aldığını tespit etmiştir. Bu sonucu destekler nitelikteki benzer bir çalışmada Güzel (2014), Antalya'da yer alan bir konaklama işletmesine yönelik yapılan yorumları incelemiştir. Çalışma sonucunda otele yönelik en fazla yorum yapılan ana temaların içinde yiyecek içecek kalitesinin yer aldığı belirlenmiştir. İstanbullu Dinçer vd., (2018) tarafından, Türkiye'de faaliyet gösteren Cittaslow dostu işletme olan Yedi Bilgeler'e yönelik yapılan yorumların değerlendirildiği çalışmada, en fazla yorumun yiyecek içecek kategorisinde yapıldığı sonucuna ulaşılmıştır. Konuyla ilgili yapılan çalışmalar incelendiğinde çevrimiçi tüketici yorumlarının en çok insan kaynakları, yiyecek-içecek ve kat hizmetleri konularında yoğunlaştığı görülmektedir. Olcay ve Giritlioğlu'nun (2014) gerçekleştirdiği çalı̧̧ma sonucunda şehir turizminde faaliyet gösteren otellerde müşteri memnuniyeti unsurlarının "Donanım, ekipman ve servis" ile "Personel" olmak üzere iki boyuta sahip olduğu tespit edilmiştir.

\section{SONUÇ VE ÖNERILER}

Yapılan çalışma sonucunda yorumların sırasıyla "insan kaynakları" temasında personelin güler yüzlü olması, "yiyecek ve içecek" temasında kahvaltı/yemeğin lezzetli olması, "kat hizmetleri" temasında ise odaların temiz olması konularında yoğunlaştığı tespit edilmiştir. Çalışma sonuçları değerlendirildiğinde insan kaynaklarına yönelik yapılan yorumların diğer konulara oranla daha fazla olması çalışanların şehir otelleri için ne denli önemli olduğunu ortaya koymaktadır. Müşterilerle birebir etkileşim halinde olan ve kendileri de birer iç müşteri olan çalışanların hizmet sunumu esnasındaki tutumları müşterilerin hafızasında yer edinmekte ve bu durum yorumlarına yansımaktadır.

Özellikle şehir merkezlerinde bulunan, kısa süreli konaklamaların gerçekleştirildiği şehir otelleri; dinlenmek, eğlenmek, doğa ile iç içe olmak ve uzun süreli tatil geçirmek için konaklamanın gerçekleştirildiği kıyı otellerinden farklı özelliklere sahiptir. Şehir otellerinde turistler tüm gün şehri keşfettikten sonra kısa süreli olarak otele yerleşip dinlenmekte ve ertesi gün erkenden ya otelden ayrılmakta ya da şehir gezisine kaldığı yerden devam etmektedir. Bu kapsamda şehir otelleri kıyı otellerinden farklı bir şekilde yönetilmedir. Çalışmanın sonuçları dikkate alındığında turistler bu otellerde en fazla personele, yiyecek içecekte kahvaltı servisine, otelin temizliğine, donanımına ve şehre yakınlık/uzaklık mesafesine önem vermektedir.

Yapılan çalışmadan elde edilen sonuçlara göre şehir turizmi alanında faaliyet gösteren konaklama işletmelerine yönelik bazı öneriler getirilmiştir. Konaklama işletmelerinin müşteri yorumlarını değerlendirmeleri ve bu yorumları bilgi kaynağı olarak görmeleri, işletmelere olumlu geri dönüşler sağlaması açısından önem taşımaktadır. Bu çalışmaya konu olan şehir 
otellerine yönelik yapılan yorumların çoğuna cevap verilmediği tespit edilmiştir. Yorumlara yanıt veren otellerin ise hepsinin dört yıldızlı olduğu anlaşılmıştır. Bu bağlamda Eskişehir'de faaliyet gösteren tüm konaklama işletmeleri çevrimiçi tüketici sitelerinde yapılan yorumlara mümkün olduğunca hızlı ve tatmin edici dönüşler yapmalıdır. İşletmeler, kendilerine yönelik yapılan bu olumlu ve olumsuz yorumları bir hediye olarak görmeli ve tehdit olarak algılanan olumsuz yorumları da fırsata çevirmelidir.

Bu kapsamda şehir otelleri, insan kaynakları departmanına gereken önemi vererek iş gören seçimi, iş başı eğitim (oryantasyon), personel ödül sistemi gibi konularda sorumluluklarını en iyi şekilde yerine getirmelidir. Çünkü turizm işletmelerinin başarısı personelin nasıl seçildiği, yönetildiği, eğitildiği, kariyer süreçlerinin nasıl desteklendiği ile yakından ilgilidir. Bu kapsamda, Eskişehir'de bulunan Anadolu Üniversitesi ve Osmangazi Üniversitesi bünyesinde turizm alanında verilen eğitimler, sektörün ihtiyacı olan kalifiye elemanın yetiştirilmesini sağlayacak niteliktedir. Müşterilerin yorumlarına yansıyan bir diğer önemli konu ise yiyecek ve içecektir. Bu kategori altında kahvaltıya yönelik yapılan yorumların çokluğu kıyı otellerindeki her şey dahil sistemden farklı olarak, şehir otellerinde genellikle oda-kahvaltı şeklinde konaklanmasına bağlanabilir. Dolayısıyla kahvaltının lezzetine, sunumuna, kalitesine önem verilmesi müşteri memnuniyetinin sağlanması açısından dikkat edilmesi gereken bir konudur. Odaların ve diğer alanların temizliği de yorumlarda sıklıkla karşılaşılması nedeniyle üzerinde durulması gereken bir diğer husustur. Bu noktada işletmelerin kat hizmetleri departmanına odaların ve diğer alanların rutin temizliğinin yapılması önerilebilir.

\section{KAYNAKÇA}

Akoğlan Kozak, M. (2005). Otel İşletmelerinde Kat Hizmetleri Yönetimi (4. Basım), Ankara: Detay Yayıncilik.

Akoğlan Kozak, M. (2009). Otel İşletmelerinde İnsan Kaynakları Yönetimi ve Örnek Olaylar (3. Basım), Ankara: Detay Yayıncilık.

Akoğlan Kozak, M., ve Bahçe, S. (2012). Özel İlgi Turizmi (2. Basım), Ankara: Detay Yayıncllık.

Arpacı, Ö., ve Vatansever Toylan, N. (2015). Turizm İşletmelerinde Bilgi Yönetimi ve Bilgi Kaynağı Olarak Müşteri Şikayetlerinin Değerlendirilmesi, Kastamonu Üniversitesi İktisadi ve İdari Bilimler Fakültesi Dergisi, (9): 50-71.

Aydın, B. (2016). Sürdürülebilir Şehir Turizmi Başarı Faktörleri ve Küçük Turizm İşletmelerinin Ekonomik Performansı, Yayınlanmamış Yüksek Lisans Tezi, Anadolu Üniversitesi, Sosyal Bilimler Enstitüsü, Eskişehir.

Banerjee, S., and Chua, A. (2016). In Search of Patterns Among Travellers' Hotel Ratings in TripAdvisor, Tourism Management, (53): 125-131.

Bilim, Y., Başoda, A., ve Özer, Ö. (2013). Elektronik Tüketici Yorumlarının Nitel Çözümlemesi ve Pazarlama Bilgi Aracı Olarak Kullanımı: Tatil Otellerine Yönelik Bir Uygulama, 14. Ulusal Turizm Kongresi, Erciyes Üniversitesi 05-08 Aralık 2013. Kayseri. ss: 387-407.

Chang, Y. C., Ku, C. H. and Chen, C. H. (2017). Social Media Analytics: Extracting and Visualizing Hilton Hotel Ratings and Reviews From TripAdvisor, International Journal of Information Management.

Creswell, J. W. (2013). Nitel Araştırma Yöntemleri. (Çeviren, M. Bütün, and S. Demir) Ankara: Siyasal Kitabevi. 
Çatı, K., ve Koçoğlu, C. (2008). Müşteri Sadakati İle Müşteri Tatmini Arasındaki İlişkiyi Belirlemeye Yönelik Bir Araştırma, Selcuk University Social Siences Institute Journal, (19): 167-188.

Çuhadar, M., Köseoğlu, S., ve Gültepe , Ö. (2018). "Isparta İlindeki Konaklama İşletmelerine Yönelik Çevrimiçi Müşteri Değerlendirmelerinin İncelenmesi: TripAdvisor Örneği". Süleyman Demirel Üniversitesi İktisadi ve İdari Bilimler Fakültesi Dergisi, 227-239.

Denizer, D. (2011). Yiyecek İçecek Hizmetleri (4. Basım), Eskişehir: Anadolu Üniversitesi Yayınları.

Doğan, N., ve Gencan , S. (2013). Seyahat Acentası Yöneticilerinin Bakış Açısıyla En Uygun Otel Seçimi: Bir Analitik Hiyerarşi Prosesi (AHP) Uygulaması, Erciyes Üniversitesi İktisadi ve İdari Bilimler Dergisi, (41): 69-88.

Doğancili, O., Ak, S., ve Karaçar, E. (2018). Göller Bölgesi'nde Yer Alan Otel İşletmelerinin TrıpAdvısor'daki Tüketici Değerlendirmeleri Üzerine Bir Araştırma, 1. Turizm Rehberliği Kongresi, Adnan Menderes Üniversitesi 29-30 Nisan 2018. Aydın. ss: 448-457.

Ekici, R., Büyükdă̆, N., ve Güven, A. (2017). Turizmde Yenilikçi Girişim: Tema Park Otel Örneği, The Fist International Congress on Future of Tourism: Innovation, Entrepreneurship Sustainability, 2830 September 2017, Mersin, Turkey. ss: 485-497.

Emekli, G. (2011). Öğrenen Turizm Bölgeleri, Kentler ve Kent Turizmine Kuramsal Yaklaşım, Ege Coğrafya Dergisi, 20(2): 27-39.

Evren, S. ve Kozak , N. (2012). Eskişehir'in Çekici Faktörlerinin Günübirlik Ziyaretçilerin Bakış Açılarıyla Değerlendirilmesi, Anatolia: Turizm Araştırmaları Dergisi, 23(2): 220-232.

Fong, L., Lei, S. and Law, R. (2016). Asymmetry of Hotel Ratings on TripAdvisor: Evidence From Single- Versus Dual-Valence Reviews, Journal of Hospitality Marketing and Management, 26(1): 6782.

Genç, K. ve Batman, O. (2018). Tarihi Konak İşletmelerine Yönelik E-Şikayetlerin Değerlendirilmesi: İpekyolu Ayaş-Sapanca Koridoru Üzerine Bir Araştırma, Uluslararası Yönetim İktisat ve İşletme Dergisi, 14(1), 283-296.

Genç, V. (2014). Eskişehir'deki Konaklama İşletmelerine İlişkin Sanal Tüketici Yorumlarının Değerlendirilmesi: TripAdvisor Örneği. 3. Disiplinlerarası Turizm Araştırmaları Kongresi, Adnan Menderes Üniversitesi 04-05 Nisan 2014. Aydın. ss: 1034-1048.

Giritlioğlu D. ve Avcıkurt C. (2010). Şehirlerin Turistik Bir Ürün Olarak Pazarlanması, Örnek Şehirler ve Türkiye' deki Şehirler Üzerine Öneriler (Derlemeden Oluşmuş Bir Uygulama), Adıyaman Universitesi, Sosyal Bilimler Enstitutsu Dergisi, 3 (4), 74-89

Güdü Demirbulat, Ö. ve Aymankuy, Y. (2016). Batum Destinasyonuna Yönelik E-Yorumların İçerik Analizi Yöntemiyle Değerlendirilmesi, 15. Geleneksel Turizm Sempozyumu, Balıkesir Üniversitesi 22 Nisan 2016. Balıkesir. ss: 69-81.

Gündüz, H. (2015). Sağlık Turizmi Kapsamında Pamukkale Termal Kaynaklarının Değerlendirilmesi ve Sağlık Bakanlığı Belgeli Otellerde Müşteri Memnuniyetinin Belirlenmesi. Yayınlanmamış Yüksek Lisans Tezi, Katip Çelebi Üniversitesi, Sosyal Bilimler Enstitüsü, İzmir.

Güzel, Ö. (2014). Deneyimsel Kritik Değer Sürücülerinin Elektronik Ağızdan Ağıza İletişimle Seyahat 2.0 Bilgi Kanallarına Yansıması: TripAdvisor.com Üzerinde Bir İçerik Analizi, Uluslararası Yönetim İktisat ve İşletme Dergisi, 10(22): 193-210. 
Hacıoğlu, N. ve Avcıkurt, C. (2011). Turistik Ürün Çeşitlendirmesi. (2.basım), Ankara: Nobel Yayın Dağıtım.

Hennig Thrau, T., Gwinner, K., Walsh, G., and Gremler, D. (2004). Electronic Word-Of-Mouth Via Consumer-Opinion Platforms: What Motivates Consumers to Articulate Themselves on The Internet?, Journal of Interactive Marketing, 18(1): 38-52.

İstanbullu Dinçer, F., Taşkıran, Ö., ve Aydoğan Çiftçi, M. (2018). Türkiye'deki İlk Cittaslow Dostu İşletme Olan Yedi Bilgeler'e Yönelik E-Yorumların Değerlendirilmesi, Türk Turizm Araştırmaları Dergisi, 2(2): 1-9.

https://tripAdvisor.mediaroom.com/tr-about-us [Erişim Tarihi: 10.04.2019].

http://yigm.kulturturizm.gov.tr/TR-9851/turizm-istatistikleri.html [Erişim Tarihi: 20.04.2019].

http://www.eskisehirkulturturizm.gov.tr/TR-111594/ulasim.html [Erişim tarihi: 23.04.2019].

Jeong, M., and Mindy Jeon, M. (2008). Customer Reviews of Hotel Experiences Through Consumer Generated Media (CGM), Journal of Hospitality and Leisure Marketing, 17(1-2): 121-138.

Jurdana, D., and Susilovic, Z. (2006). Planning City Tourism Development: Principles and Issues. Tourism and Hospitality Management, 2(12): 135-144.

Kozak, N., Akoğlan Kozak, M., ve Kozak, M. (2017). Genel Turizm: Ilkeler-Kavramlar. (19. Basım), Ankara: Detay Yayıncllık.

Kuru , G. (2005). Otelciliğin İncelikleri (1. Basım), İstanbul: Ekin Grubu.

Law, R. (2006). Internet and Tourism -Part XXI, Journal of Travel and Tourism Marketing, 20(1): 7577.

Lee, C., and Hu, C. (2005). Analyzing Hotel Costomers' E Complaints From an Internet Complaint Forum, Journal of Travel and Tourism Marketing, 17(2): 167-181.

Limberger, P., Anjos, F., Souza Meira, J., and Anjos, S. (2014). Satisfaction in Hospitality on TripAdvisor.com: An Analysis of The Correlation Between Evaluation Criteria and Overall Satisfaction, Tourism and Management Studies, 10(1): 59-65.

Lin, H. H., and Wang, Y. S. (2006). An Examination of the Determinants of Customer Loyalty in Mobile Commerce Contexts, Information and Management, 43(3): 271-282.

Nicoli, N., and Papadopoulou, E. (2017). TripAdvisor and Reputation: A Case Study of The Hotel Industry In Cyprus, EuroMed Journal of Business, 12(3): 316-334.

Olcay, A.,ve Giritlioğlu, İ. (2014). Gaziantep Bölgesinde Şehir Turizmine Hizmet Veren Otellerde Müşteri Memnuniyeti Üzerine Bir Araştırma. Electronic Journal of Social Sciences, 13(50): 1-22.

O'Connor, P. (2010). Managing a Hotel's Image on TripAdvisor, Journal of Hospitality Marketing and Management, 19(7): 754-772 .

Ok, S., Suy, R., Chhay, L., and Choun, C. (2018). Customer Satisfaction and Service Quality in the Marketing Practice: Study on Literature Review, Asian Themes in Social Sciences Research: 1(1), 2127. 
Reiter, C. (2007). Travel Web Sites Clamp Down on Bogus Reviews. [Online] https://www.reuters.com/article/us-hotels-casinos-summit-web-travel1/travel-web-sites-clampdown-on-bogus-reviews-idUSN1422466620070216 [Erişim tarihi: 10.04.2019].

Sarışık, M. (2016). Otel İşletmelerinde Yiyecek İçecek Hizmetleri Yönetimi, (Editör) Akoğlan Kozak M.: Otel İ̧sletmeciliği içinde (ss. 239-257) Ankara: Detay Yayıncılık.

Seçilmiş, C., ve Kılıç, İ. (2018). Turistik Destinasyonlarda Yerel Halk ve Turist Gözünden Taşıma Kapasitesinin Değerlendirilmesi: Eskişehir Örneği, Seyahat ve Otel İşletmeciliği Dergisi, 15(3): 506522.

Silverman, D. (2005). Doing Qualitative Research: A Practical Handbook. (2. Basım), Londra: Sage Publications.

Uca Özer, S. (2010). Şehir Turizmi ve Kültür: Yabancı Turistlerin Kültürel Bir Destinasyon Olarak İstanbul'u Değerlendirmeleri Üzerine Bir Araştırma, Yayınlanmamış Doktora Tezi, Anadolu Üniversitesi, Sosyal Bilimler Enstitüsü, Eskişehir.

Uca, S. (2019). Şehir Turizmi. (1. Basım), Ankara: Detay Yayıncılık

Yıldırım, A., ve Şimşek, H. (2006). Sosyal Bilimlerde Nitel Araştırma Yöntemleri. (6. Basım), Ankara: Seçkin Yayıncılık. 